\title{
THE REGION: PLACE OR PROCESS?
}

\author{
Lowell D. Ashby*
}

I recently came across a controversy among geographers. I quote from a scholarly work published in 1976 concerned with defining the proper scope of geography (Dickson, 1976):

"Economists and sociologists despise concern with places. They are concerned with process and abstract generalization."

"Regional science... has swept the colleges of the USA like wildfire ... .

"... there is today an exaggerated devotion to the quantitative analysis of geographic variable' that masquerades under the banner of 'regional science' and 'the new geography."'

This particular scholar abhors narrow specialization and what he calls

". . the pursuit of process as an end in itself."

I had not been aware that some of the leading traditional geographers have two perceptions: (1) that graduate students are often lured by the dubious charms of quantitative methods into regional science, and (2) that traditional geography itself is under siege from the ongoing depredations of concern with process as opposed to concern with place.

Nevertheless the same issue arises, in a different form, in economics. There were the early critics who questioned whether regional science was a discipline worthy of the career commitment of competent students-presumably because it was too "place" oriented, that is, not sufficiently general. The economics profession has long contemplated models of economic activity of great generality but with no particular geographic coordinates. And in the opposing camp we recall Walter Isard's allusions to the "dimensionless wonderland" of the economic theoretician.

We have here an interesting duality. Some geographers have been criticized for being too process oriented and wandering into the limbo

*U.S. Department of Commerce (ret.), Fellow, S.R.S.A. Paper presented at the annual meeting of the Southern Regional Science Association, Washington, D.C., May 11, 1985. of regional science. At the same time some economists have been criticized for not being sufficiently process oriented and wandering into that same limbo.

To the economist, of course, the process is the market process. And to many an economist there is no social ill of any kind that cannot best be managed by the market processproperly understood and applied.

A good illustration of the pervasive concern about place and process is the debate about industrial policy. This debate has been underway for at least a quarter of a century and has deep roots in United States' economic history.

Superficially the debate would appear to be about whether we should have an industrial policy and, by implication, its flip side-a regional policy. Such a debate would be pointless since we have and always have had an industrial/regional policy. But the programs growing out of these policies have dealt-in economic jargon-with externalities. That is, they have been conceded to deserve management by ways and means external to the process. So the debate is not about whether there should be policies and programs to handle externalities, but rather where we draw the line between what is internal and what is to be considered external to the market process.

There are those who urge additional governmental programs (federal, state or local) designed to deal with specific industrial and regional problems. ${ }^{1}$ In their view, the market process cannot properly deal with these problems because the pace of change has become too rapid. It required four generations to achieve a drastic reduction of agricultural production employment in response to technological change. But more recently many industrial participants have been left without protection because it took only one generation to achieve equivalent reductions in steel, autombiles, electrical equipment and footwear. There have been associated serious slippages in the workers' position on the income distribution. Even where new jobs have been found, the slippage has been typically from lower middle class status down to the vicinity of the officially defined poverty line for a family of four. 
The proponents of change assert that whether we recognize it or not, we are living in a neo-mercantile age. Japan, for example, has built steel and shipbuilding industries-not for immediate profit but as infra-structure. With these industries in place, many other industrial consequences follow. Their attitude is the same as that which built an inter-state highway system in the United States. It is not a profitmaking enterprise. It is infra-structure.

Those opposing further encroachment on the market process point out that such policies have not solved the unemployment problem in Europe. Moreover, we do not want a rigid system where no one can change position on the income scale. Nor do we want to prevent increases in productivity which accompany technological advance by stifling the associated displacement of workers. They readily admit that there are externalities which demand nonmarket intervention. But they insist that we do not have systematic misallocation of resources within the conventional private economy.

Furthermore, the opponents argue, if we are to intervene, the market process has to be replaced by something. There must be objective criteria to guide some governmental authority. But even if we developed the criteria and made the choices, the political system would not permit their implementation. What workers and what regions, for example, together with their duly elected representatives and senators, are willing to admit that they are obsolete and should be left solely to the mercies of the market process?

The immediate rejoinder of the proindustrial policy advocates is that workers and regions do not admit that they are obsolete because they are not and cannot be obsolete. They carry intrinsic values which are worthy of support and preservation. People and places do not become obsolete; only machines and arrangements become obsolete.

This sharpens the issue. The concern is not merely for the place of people in a geographic sense but also for their place in the community. In pre-industrial times, one's place in the economy depended on one's place in society. With the industrial revolution this was turned around. One's place in society came to depend on one's place in the economy (Polanyi, 1944). This remains largely true today. The debate goes on as to how to deal with people who, for whatever reason, have lost attachment to the economy and with it attachment to community and society.

The problems have proved so intractable that new voices are being given a hearing. Michael J. Piore, economist, and Charles F. Sabel, political scientist, both of M.I.T., contend that we have reached a second industrial divide (1984). The first occurred in the 19th century with the emergence of mass production technologies. At that time, initially in Britain and later in the United States and elsewhere, the rigid mass production structure pushed aside and eventually submerged the more flexible craft system.

The displacement has been so complete that even union structure, shop work space, and dispute settlement go on as if the crafts have disappeared. Increasingly the bargaining process concerns sterile legal issues and procedural rules-and less and less the substantive work at hand. While the procedures have proliferated, work satisfaction, quality of work and sense of community have declined.

However it may be obscured, a core of craft production remains. For example, we usually think of highly specialized machines repeating their function over and over in turning out specialized products. But these highly specialized machines were not themselves mass produced. They were and are the creation of artisans and adaptive craftsmen.

At this second industrial divide it is clear that change of any kind requires flexibility, and the time for rethinking is at hand. A partial restructuring of our industrial establishment along craft lines is an option being urged to achieve a stronger attachment to community and a diminished intensity of hierarchical labor-management confrontation.

The proponents of industrial policy and the proponents of a return to craft production appear to agree that total faith cannot be placed in the market process alone even for the conventional private economy; structural changes are needed which give due regard to the geographic and social place of our industrial participants.

Jane Jacobs in her recent book, Cities and the Wealth of Nations, Principles of Economic Life (1984), looks at the industrial policy debate from a unique point of view. ${ }^{2}$ She takes note of the recurrent condition which fuels the controversy-the coexistence of stagnant 
growth and inflation, or "stagflation." Jacobs surveys the response of economists to this condition, starting with the French and English in the 18 th century. The long standing view even among the Marxists is that a trade-off exists between economic activity and prices. More economic activity and less unemployment equals higher prices; less economic activity and more unemployment equals lower prices.

In other words, says Jacobs, the long standing view has been that stagflation does not exist except in unusual or aberrant situationsin the normal course of events, stagnant growth and inflation do not go together. While proceeding on this basic assumption, the economics profession in the post World War II period has nevertheless witnessed the continued recurrence of stagflation in the United States and elsewhere, despite the successive policy prescriptions of the Keynesians and the monetarists. And while the United States shares this condition with other capitalist economies, there is no complacency in the Marxist-socialist countries. In fact the condition is even worse there, though often veiled by industries with redundant workers, price subsidies and defaulted loans from the United States, western Europe and Japan.

A life-long student of the city, Jane Jacobs is convinced that stagflation is the normal and ordinary condition to be found in poor and backward economies the world over, as it always has been. The idea that it is a recent western phenomenon and that it is both transitory and abnormal has been current only in the developing or expanding economies. But these are the same economies which produced the prominent economists and most of the economic literature.

Moreover, the emergence of stagflation in formerly developing economies such as England, the United States and Canada is appalling in its implications. It is not just a problem of inflation to be controlled along with unemployment. Rather it is a condition in its own right which threatens us with reversion toward a world-wide norm. Taking her most controversial yet central stance, Jacobs (1984, p. 29) says of macro-economic theory that a basic unexamined assumption is in error:

"It is the idea that national economies are useful and salient entities for understanding how economic life works and what its structure may be: that national economies and not some other entity provide the fundamental data for macro-economic analysis. The assumption is about four centuries old, coming down to us from the early mercantilist economists who happened to be preoccupied with the rivalries of European powers ..." In short, economists have been playing in the wrong ball park for 400 years! And what is the correct ball park? It is the vital city and the surrounding city region. The strength and vitality of nations derives from the city regions they are so fortunate as to contain, and not the reverse.

Why are cities and city regions indispensable? Because they are capable of producing for themselves and for export. This capability arises through "import replacement." Any settlement that becomes good at import-replacing becomes a city. Any city that repeatedly experiences episodes of import replacement keeps its economy up-to-date and remains capable of casting forth steams of innovative export work.

Standing in contrast to cities and city regions with their import-replacing capacity are supply regions. Supply regions, whether initially rich or poor, lack developmental capacity. Consequently they eventually become poor. Supply regions are narrowly specialized and therefore find themselves wholly dependent on areas that singly, or together, demand their one product. When, due to technological shift, demand for this one product disappears, the supply region lacks the flexibility to turn to new tasks. Then it becomes impoverished.

Says Jacobs (1984, p. 71):

"An economy that contains few different niches for people's differing skills, interests and imaginations is not efficient. An economy that is unresourceful and unadaptable is not efficient. An economy that can fill few of the needs of its own people and producers is not efficient. To say that the economy of Uruguay ... was more efficient because more specialized than the economy of Switzerland is to stand reality on its head."

There are a number of corollaries to the proposition that a nation's economic vitality is a creature of the vitality of its cities and city regions.

Economic development carnot be hought, borrowed, stolen or even given away; it must be accomplished, starting with the particular circumstances and opportunities at hand. We 
have lived through a period of failed development schemes-disasters as in Poland, Iran, Uruguay, Argentina, Brazil, Mexico, Turkey, and much of Africa-as well as disappointments in Ireland, Canada, southern Italy, Yugoslovia, Cuba and India. The Shah of Iran's attempt to transplant a helicopter factory from Forth Worth to Isfahan turned out no better than Peter the Great's attempt to buy an industrial economy from western Europe.

What has been demonstrated between nations has also been evident within nations. While the more affluent portions of nations can alleviate poverty in the poorer areas, they cannot thrust development upon these areas.

But while the vitality of nations is drawn from their cities, the development of cities is often stultified by national policies. For example, national currency exchange rates often reenforce the growth of dominant cities while undermining the development of others.

While there are transactions of development, there are the opposites-transactions of decline. Such transactions are the inevitable accompaniment of the attempt to sustain huge national states. Among such transactions are: military garrisons and expenditures; welfare subsidies; regional subsidies; transfer payments; and repeated supply region investment, without equivalent return to the productive cities. Jacobs $(1984$, p. 200) makes the none too optimistic assessment at one point that:

"Today the Soviet Union and the United States each predicts and anticipates the economic decline of the other. Neither will be disappointed."

In short, nation-states are today in a predicament-not by choice but by circumstance. There is a possible way out through the splitting of economic sovereignties. Examples include: the privileged position of Hong Kong, the separation of Norway from Sweden in 1905 , and the separation of Singapore from Malaysia. However, this course is only hypothetical.

In the absence of a direct remedy, there is an ameliorating approach. Tadao Umesao, Japanese anthropologist, has observed that historically the Japanese have always done better when they drifted in an empirical, practical fashion than when they attempted to operate by "resolute purpose" and "determined will." He called this an "esthetics of drift" and believed it uniquely Japanese. A similar idea has been expressed by Cyril Stanley Smith, (Jacobs, 1984, p. 223), emeritus professor of metallurgy at M.I.T.:

"All big things grow from little things, but new little things are destroyed by their environment unless they are cherished for reasons more like esthetic appreciation than practical utility."

Jacobs contends that open-ended drift is appropriate in all culture since it is akin to the course of biologic evolution. The analogy is also with natural ecology. The more diversity there is, the more flexibility because of what ecologists call the greater number of "homeostatic feedback loops." It is the same with economies-too few feedback loops render nations disastrously unstable economically and their cities so poor at self correction.

Starting in 1979 in the United States, the Federal Reserve Board moved to a monetarist stance, and the newly elected Reagan Administration adopted a combination of monetartist and supply-side policies. But today we have the stress of an intractable unemployment level, and our greatest domestic policy issue of the moment centers around the federal deficit and its linkage with high interest rates. The general disillusion with Keynesian, monetarist, and supply-side remedies for stagflation has put the "rational expectationists" at center stage. The rational expectationists reject the idea of a managed economy outright. What is left is the belief that the economy acts as well as being acted upon. For every policy move there is a counter move of the affected economic units, which acts to hedge or even negate the policy action. In the light of this renewed realization (for rational expectations theory is not entirely new), the correct policy is thought to be a minimal one. What is definitely not wanted is active macro-policy.

To sum up, the Keynesians, the monetarists, the supply-siders and even the socialists have told us that they understand the economic process well enough to make macro-interventions successfully. The rational expectationists now tell us that they understand the process well enough not to attempt macro-interventions.

My impression has been that among geographers the intellectual movement has been away from the traditional place and people orientation and toward a more rigorous theo- 
retical or process oriented stance.

When I project this issue into the literary space occupied by economists and their critics, I gain a contrary impression. "Stagflation" continues to fuel the industrial policy debate. This, in turn, is bringing forth a new harvest of ideas-many of which will inevitably receive critical reviews of the type that what is new is not true and what is true is not new. It is important to recognize, however, that these ideas are receiving a different kind of hearing than would have been given in 1965 . The reason for this is that macro-policy is not pre-empting economic literature in the same way as it once did. This results from the experience of events.

Paul Samuelson has suggested that the "complacency index" among economists stood at 100 in 1965 and was already down to 40 by 1975 (Lee, 1984, p. 150). A few years back when something went wrong with the economy it was thought that someone in Washington should do something about it. But, as observed by Martin Feldstein, during the 1982 recession there was hardly any call from either professional economists or elected officials for the government to do something (Lee, 1984, p. 158). The intellectual climate has changed. Perhaps it is now a blend of the economic theory of rational expectations and the philosophy of esthetic drift.

Something of an official recognition of this climate was implied by Charles L. Schultze at the conclusion of his presidential address to the American Economic Association in 1984:

"Conceivably, economics, like physics, is subject to a fundamental indeterminacy theorem."

Where do regional scientists in general and regional economists in particular stand with respect to this intellectual kaleidoscope? They have largely avoided macro-policy issues because they have been concerned with urban development, city planning, demographic and economic measurement and even with human geography. Out of the consultative mainstream of national economic management, they now hear that the national economy cannot be managed in any case. They also hear that for fundamental, but overlooked reasons, the real source of economic development is not the national state but rather the city and the city region.

I conclude that the instinct of the founders of regional science has been fundamentally correct in its concern with geographic, economic and social place-as opposed to an exclusive concern with a geographically dimensionless and abstract economic and social process.

We may still be lacking in both place orientation as viewed by some geographers, and in process orientation as viewed by some economists. But it increasingly appears that we have been playing in the right ball park-the one which provides the competitive context for life-enhancing insight and innovation.

\section{FOOTNOTES}

\begin{abstract}
'In discussing the issues concerning industrial policy, I have taken note of a debate "De-Industrialization of the American Economy-Myth or Reality" sponsored by the Institute of Politics of Harvard University in 1984. The moderator was Benjamin M. Friedman(Harvard University). The participants were Barry Bluestone (Boston College); Bennett Harrison (Massachusetts Institute of Technology); Robert Z. Lawrence (Brookings Institution); Charles L. Schultze (Brookings Institution). Tape available from The Forum, The Institute of Politics, P.O. Box 1666, Cambridge, Massachusetts 02238, 1984.

${ }^{2}$ Discussions of unemployment and inflation as well as appropriate policy prescriptions permeate economic literature since the 17 th century. For reference to the recent sequence of interventionist policies see Jane Jacobs (1984).

${ }^{3} \mathrm{Jacobs}(1984$, p. 216$)$ speaks of cities as providing the ideal context for innovations (inputs of human insight) and replacements of imports (inputs of the human capacity to make adaptive imitations). In the undeveloped economy, the city may provide the only such context. However, it is not clear that she should or would exclude other contexts for such innovations and replacements in developed economies. For example, the recent development of computer networking has the effect of bringing together widely dispersed workers into a "city-like" web of communication and interaction. Also there is much that is new in inter-region, inter-state, inter-industry and interfirm research and development. See Norris 1985, pp. 92102).
\end{abstract}

\section{REFERENCE}

Dickson, Robert E. The Regional Concept: The AngloAmerican Leaders. Routledge \& Kegan Paul, London, Henley and Boston, 1976, 354.

Jacobs, Jane. Cities and the Wealth of Nations, Principles of Economic Life, Random House, New York, 1984, passim.

Lee, Susan. "The Un-Managed Economy," Forbes, December 17, 1984, passim.

Norris, William C. "Cooperative R \& D: A Regional Strategy," Issues in Science and Technology, Winter 1985, 92-102.

Piore, Michael J. and Charles F. Sabel. The Second Industrial Divide, Possibilities for Prosperity. Basic Books, Inc., Publishers, New York, 1984, passim.

Polanyi, Karl. The Great Transformation. Rinehart, New York, 1944, passim.

Schultze, Charles L. "Microeconomic Efficiency and Nominal Wage Stickiness." The American Economic Review, Volume 75, Number 1, March 1985, 15. 